\begin{tabular}{lccc} 
VERSITA & GOSPODARKA & SUROWCAMI & MINERALNYMI \\
\hline \multirow{2}{*}{ Tom 29} & 2013 & Zeszyt 3 \\
& & DOI 10.2478/gospo-2013-0036 &
\end{tabular}

\title{
Possibility of Huntite presence in the Triassic limestones of Opole Silesia
}

\section{Introduction}

Sediments of the eastern part of the epicontinental Germanic Basin, which include Triassic carbonate rocks (Middle Triassic-Muschelkalk), are situated in the area of Opole Silesia. The content of $\mathrm{Mg}$ and $\mathrm{Ca}$ in these rocks varies. Differentiation of Muschelkalk sediments is the effect of deposition conditions in the Germanic Basin (Szulc 1990, 2000). Muschelkalk sediments were formed in an environment of successive sea transgressions and regressions. Variable amounts of $\mathrm{CaO}$ and $\mathrm{MgO}$ are characteristic for carbonate rocks of Opole Silesia. It is possible to observe these in the limestones of the Gogolin Beds, Górażdże Beds, Dziewkowice Beds, and Karchowice Beds, not only in the vertical profile, but also within each formation (Stanienda 2006, 2011; Szulc 1990, 2000). The original composition of the Triassic rocks, not only those from the area of Opole Silesia but also the rocks from Upper Silesia (Stanienda et al. 2012), was also modified during diagenetic processes which were taking place inside the rocks. The results of studies executed till now show that the Triassic limestones of Opole Silesia are mainly comprised of low magnesium calcite, $\mathrm{Mg}$-calcite, and dolomite. These carbonate phases dominate in the rocks. Lesser amounts of ankerite and siderite were observed (Stanienda 2006, 2011; Szulc 1990, 2000). Huntite is a carbonate phase characterized by a higher content of magnesium than Mg-calcite and dolomite, but lower than magnesite. The presence of huntite in carbonate rocks of Opole Silesia extends the data on mineral composition of carbonate rocks from the area of Opole

* Dr inż., Instytut Geologii Stosowanej, Wydział Górnictwa i Geologii, Politechnika Śląska, Gliwice, e-mail: katarzyna.stanienda@polsl.pl 
Silesia. It could also be a source of new information about the conditions of carbonate material deposition during Muschelkalk formation in the Germanic Basin, especially with respect to the salinity of seawater in the eastern part of this basin. This article presents the results of preliminary research which confirmed the presence of huntite in the Triassic limestone of Opole Silesia.

\section{Methodology of study}

Huntite was identified using three research methods: FTIR analysis, X-ray diffraction, and studies carried out in microareas (microprobe measurements).

The Fourier analysis in the infrared spectrum (FTIR) was applied to investigate four samples: one sample of Gogolin limestones (sample 1 from Gogolin), one sample of Górażdże limestones (sample 2 from Ligota Dolna), and two samples of Terebratule (Dziewkowice) limestones (sample 3 from Strzelce Opolskie and sample 4 from Szymiszów). This method uses selective absorption of light by minerals. The studies were carried out at the Institute of Geological Sciences of Jagiellonian University using the Fourier spectrometer FTS 135 BioRad. The spectra were elaborated using the software provided by the manufacturer (Bio-Rad Sadtler Division 1981-1993).

X-ray diffraction was applied to examine five samples altogether: one sample of Gogolin limestone (sample 1 from Gogolin), two samples of Dziewkowice (Terebratule) limestones (sample 3 from Strzelce Opolskie and sample 4 from Szymiszów), and two samples of Karchowice limestone (sample 5 and sample 6 from Strzelce Opolskie). The X-ray diffraction analysis was carried out at the Institute of Applied Geology in Gliwice, using the diffractometer HZG4, applying a copper lamp with a nickel screen and the following analysis conditions: voltage $35 \mathrm{kV}$, intensity $18 \mathrm{~mA}$. The method of reflective light was used here.

Studies in microareas examined three samples: one sample of Dziewkowice limestone (sample 4 from Szymiszów) and two samples of Karchowice limestone (sample 5 and sample 6 from Strzelce Opolskie). The studies were carried out at the Institute of Non-ferrous Metals in Gliwice. The analyses were conducted using the techniques of X-ray microanalysis EPMA, with the application of X-ray microanalyser JXA-8230 manufactured by JOEL. The examinations were performed on polished sections which were sputtered with a carbon coat. The analysis with the application of WDS spectrometers was carried out in microareas 1 and 2 of sample 4, in microareas 1 and 2 of sample 5 , and in the microarea 1 of sample 6 . The WDS method was applied to conduct quantitative analyses in microareas with a size of $60 \times 45 \mu \mathrm{m}$ (magnification 2000x) for selected points having different chemical compositions. The content of the following chemical elements was determined: $\mathrm{Mg}, \mathrm{Si}, \mathrm{Al}, \mathrm{Ca}, \mathrm{K}$, $\mathrm{Ba}, \mathrm{Sr}, \mathrm{Fe}, \mathrm{Mn}$, as well as instances of $\mathrm{O}$ and $\mathrm{C}$. Because carbonates burn during exposure to $\mathrm{X}$-rays, it was necessary to calculate values of $\mathrm{O}$ and $\mathrm{C}$ to normalize the results of measurements to a value of $100 \%$. The total amount of $\mathrm{C}$ and part of the oxygen formed carbonates. The rest of the $\mathrm{O}$ formed aluminosilicates and quartz. 


\section{Results of study}

\subsection{Results of FTIR spectroscopy}

Based on the absorption spectra obtained from the Fourier analysis in the infrared spectrum (Fig. 1), the minerals forming constituent parts of the examined limestones were identified, in particular carbonate phases (Table 1).

Carbonate minerals are characterized by highly anisodesmic bonds. Anions $\mathrm{CO}_{3}{ }^{2-}$ in the minerals in which atoms have covalence bonds behave like vibrators, with little dependence on the surroundings. Their vibrations have, in principle, an influence on the absorption spectra of carbonates. The absorption bands, corresponding to the intramolecular vibrations of $\mathrm{CO}_{3}{ }^{2-}$ anions, correspond to the basic infrared range, and the lattice vibrations yield absorption bands in the far infrared (Ahn et al. 1996; Bolewski, Żabiński 1988; Pokrovsky et al. 2000; Ramseyer et al. 1997). In the analyzed samples, low-magnesium calcite predominates. Huntite was identified in four examined rocks. In some samples, other carbonate phases like Mg-calcite (magnesium calcite, magnesio-calcite) (samples 1,2) and dolomite (samples 3,4) were also identified, as well as non-carbonate phases ? feldspars (samples 1, 2, 3, 4), clay minerals (samples 1, 2, 3), quartz (samples 1, 2), and hydrargillite (gibbsite) (samples 1, 2, 3, 4). Huntite - $\mathbf{C} \mathbf{a M g}_{3}\left[\mathbf{C} \mathbf{O}_{3}\right]_{4}$ - a carbonate phase of higher magnesium content than dolomite, was identified based on the infrared bands of the values $1555 \mathrm{~cm}^{-1}$ in samples 1 and $4,1562 \mathrm{~cm}^{-1}$ in sample 3, and $1572 \mathrm{~cm}^{-1}$ in sample 2 (Table 1 , Fig. 1) (Ramseyer et al. 1997; http://rruff.info/Huntite). However, huntite was only identified based on single bands, and only in the limestones of the Gogolin, Górażdże, and Dziewkowice Beds. Moreover, there is a small amount of this carbonate phase mixed with other carbonates among which low magnesium calcite predominates. Therefore, it was necessary to carry out additional studies confirming the presence of this carbonate phase in the Triassic limestones of the Opole Silesia Region.

\subsection{Results of X-ray diffraction}

The results of X-ray diffraction indicate that huntite could be present in six of the samples (Table 2, Fig. 2). The mineral occurs in small amounts. It was identified based principally on the diffraction line of the highest intensity (Dollase, Reeder 1986; http://webmineral.com/data/Huntite.shtml), although it is not difficult to identify different carbonate phases in the carbonate mixture, usually calcite and dolomite (Pawloski 1985). For most of the samples, however, low-magnesium calcite is the dominant phase (Table 2, Fig. 2). It was confirmed by the presence of a number of diffraction lines typical for that phase. The Karchowice limestones are the exception here - samples 5 and 6 (Table 2, Fig. 2e and 2f) where, in the X-ray diffraction pattern, high intensity diffraction lines coming from dolomite are predominating. This mineral is also present, although in lower quantity, in the Dziewkowice limestones (samples 3 and 4) (Table 2, Fig. 2c and 2d). Furthermore, 
82

焉焉焉

\begin{tabular}{|c|c|c|c|c|}
\hline 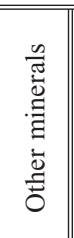 & 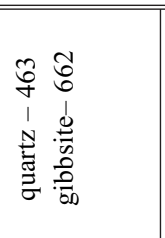 & 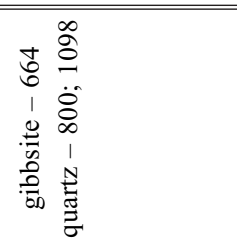 & 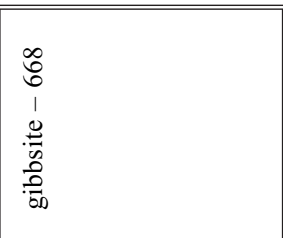 & 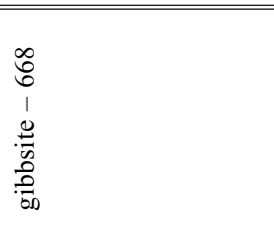 \\
\hline 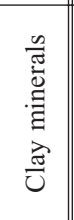 & 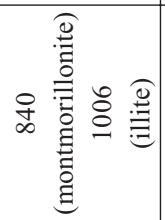 & 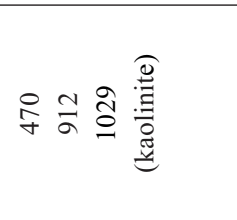 & 气営 & 1 \\
\hline 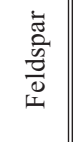 & $\stackrel{8}{\circ}$ & శึ & $\bar{\gamma}$ & ఫิ \\
\hline 童 & 点 & $\frac{n}{n}$ & 它 & 点 \\
\hline 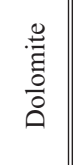 & 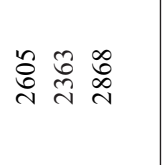 & 1 & 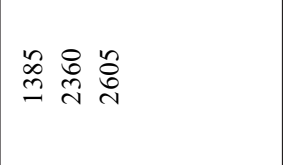 & : \\
\hline 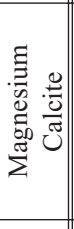 & $\begin{array}{l}\text { 吾 } \\
\text { 11 } \\
\text { 11 } \\
> \\
+ \\
>\end{array}$ & $\begin{array}{l}\underset{n}{g} \\
\underset{y}{11} \\
>^{n}\end{array}$ & 1 & 1 \\
\hline$\frac{\frac{\mathscr{g}}{\tilde{J}}}{\frac{\pi}{U}}$ & 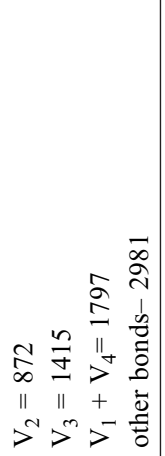 & 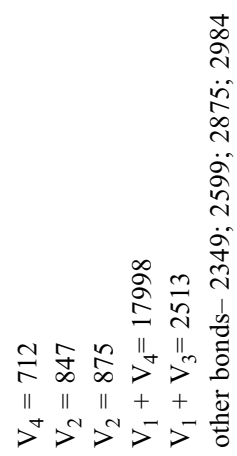 & 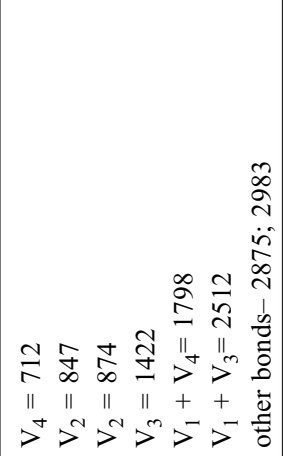 & $\begin{aligned} 0 \\
\\
\end{aligned}$ \\
\hline 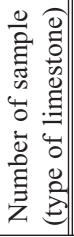 & 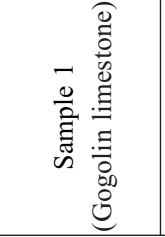 & 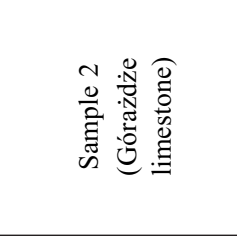 & 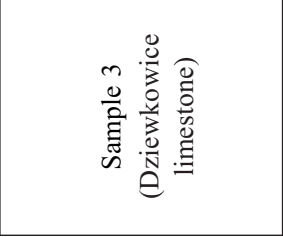 & 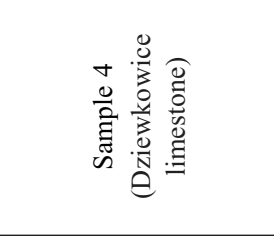 \\
\hline
\end{tabular}




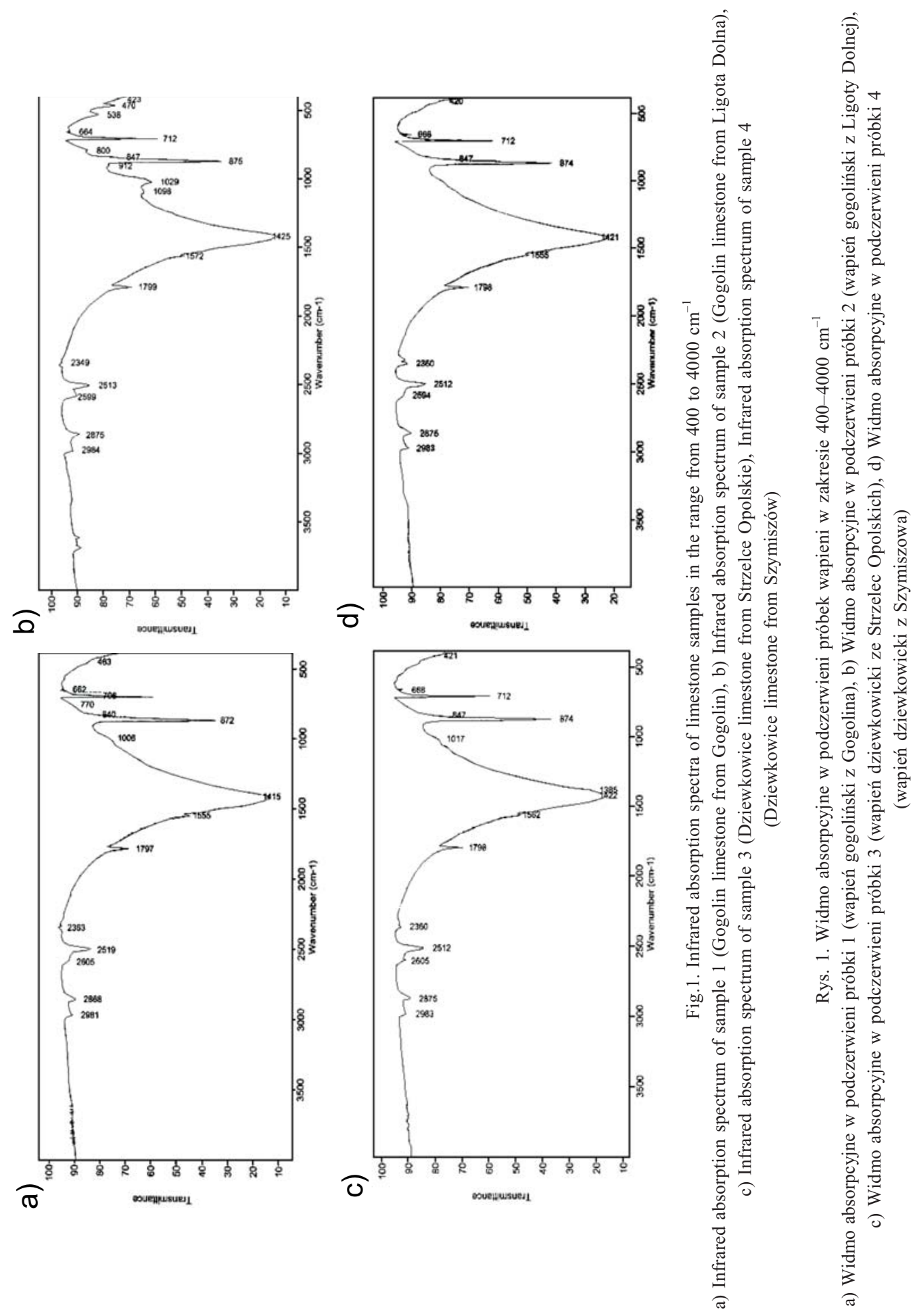



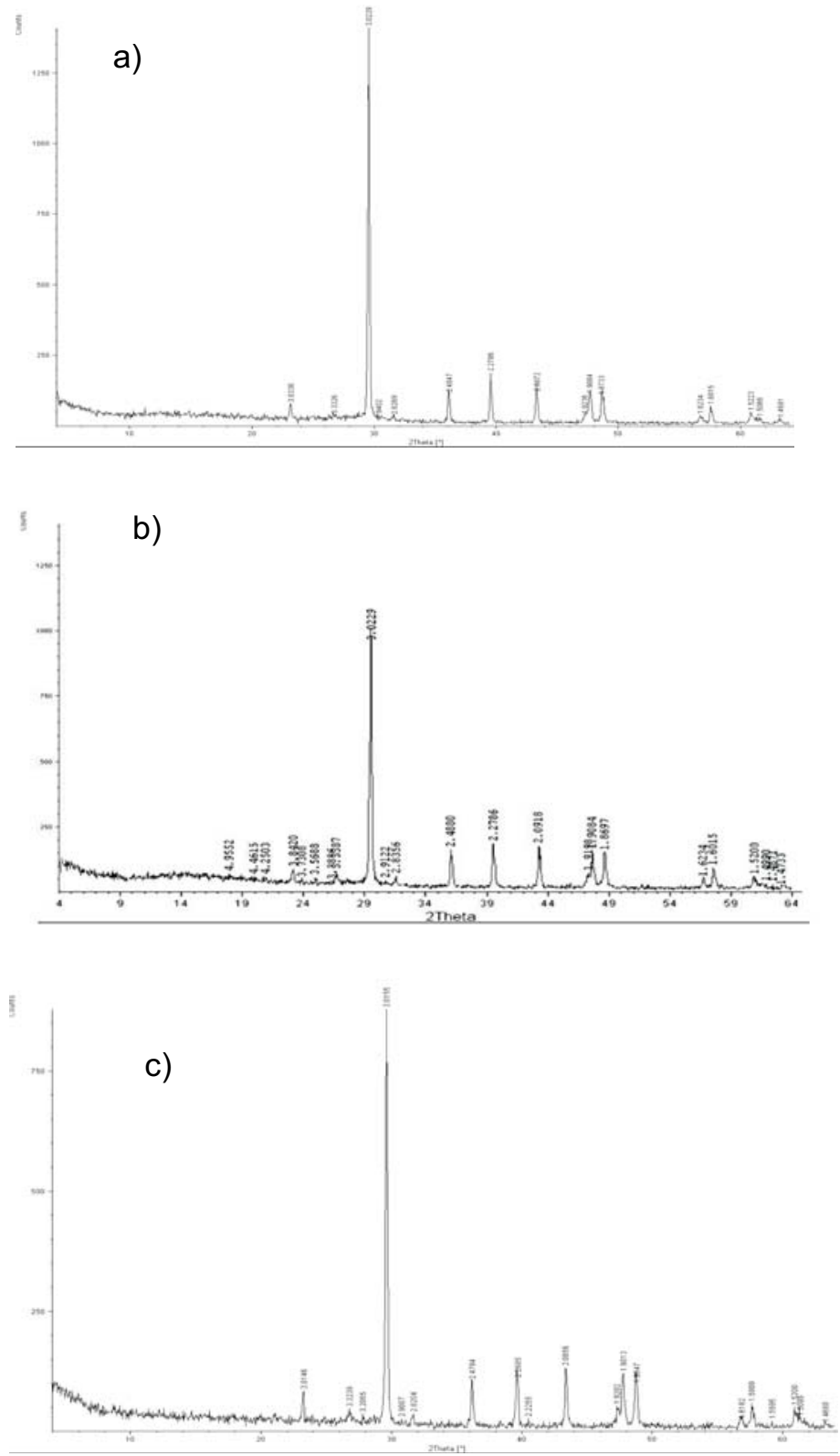

Fig. 2. X-ray diffraction patterns of limestone samples

a) X-ray diffraction pattern of sample 1 (Gogolin limestone from Gogolin),

b) X-ray diffraction pattern of sample 2 (Górażdże limestone from Ligota Dolna),

c) X-ray diffraction pattern of sample 3 (Dziewkowice limestone from Strzelce Opolskie)

Rys. 2. Dyfraktogram próbek wapieni

a) Dyfraktogram próbki 1 (wapień gogoliński z Gogolina),

b) Dyfraktogram próbki 2 (wapień Górażdże z Ligoty Dolnej),

c) Dyfraktogram próbki 3 (wapień dziewkowicki ze Strzelec Opolskich) 

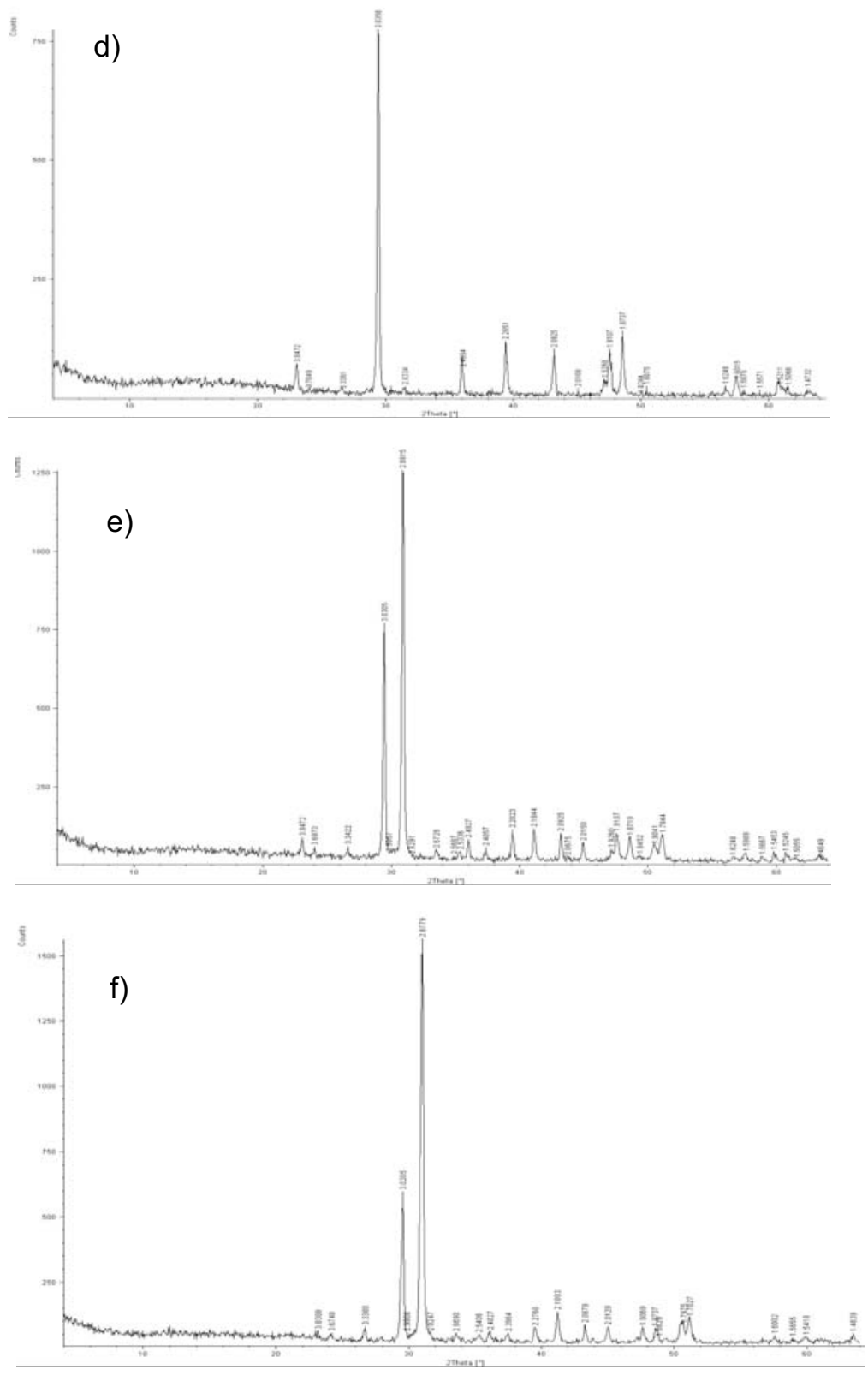

Fig. 2. X-ray diffraction patterns of limestone samples

d) X-ray diffraction pattern of sample 4 (Dziewkowice limestone from Szymiszów),

e) X-ray diffraction pattern of sample 5 (Karchowice limestone from Strzelce Opolskie),

f) X-ray diffraction pattern of sample 6 (Karchowice limestone from Strzelce Opolskie)

Rys. 2. Dyfraktogram próbek wapieni

d) Dyfraktogram próbki 4 (wapień dziewkowicki z Szymiszowa),

e) Dyfraktogram próbki 5 (wapień karchowicki ze Strzelec Opolskich),

f) Dyfraktogram próbki 6 (wapień karchowicki ze Strzelec Opolskich) 
Results of X-Ray Diffraction

TABELA 2

Wyniki analizy rentgenostrukturalnej

\begin{tabular}{|c|c|c|}
\hline $\begin{array}{l}\text { Number of sample } \\
\text { (type of limestone) }\end{array}$ & Mineral & $\begin{array}{c}\mathrm{d}_{\mathrm{hkl}}-\text { index of the lattice intervals of exposed parallel lattice planes system, } \\
\text { I - intensity of diffraction lines (in brackets) }\end{array}$ \\
\hline \multirow{4}{*}{$\begin{array}{c}\text { Sample } 1 \\
\text { (Gogolin limestone) }\end{array}$} & calcite & $\begin{array}{c}3.8338(12), 3.0229(100), 2.4847(12), 2.2786(15), 2.0872(15), 1.9236(5), \\
1.9084(15), 1.8733(15), 1.6234(4), 1.6015(8), 1.5223(5), 1.5066(3), 1.4691 \\
(5)\end{array}$ \\
\hline & huntite & $2.8269(100)$ \\
\hline & ankerite & $2.9402(100)$ \\
\hline & quartz & $3.3326(100)$ \\
\hline \multirow{6}{*}{$\begin{array}{l}\text { Sample } 2 \\
\text { (Górażdże } \\
\text { limestone) }\end{array}$} & calcite & $\begin{array}{c}3.8420(12), 3.0229(100), 2.4880(12), 2.2786(15), 2.0918(15), 1.9198(5) \\
1.9084(15), 1.8697(15), 1.6234(4), 1.6015(8), 1.5200(5), 1.4990(3) \\
1.4871(5), 1.4733(5)\end{array}$ \\
\hline & huntite & $2.8356(100)$ \\
\hline & ankerite & $3.7308(10), 2.9122(100)$ \\
\hline & quartz & $4.2503(20), 3.3387(100)$ \\
\hline & illite & $4.9552(60), 4.4615(60), 3.3886(100)$ \\
\hline & kaolinite & $3.5688(80)$ \\
\hline \multirow{4}{*}{$\begin{array}{l}\text { Sample } 3 \\
\text { (Dziewkowice } \\
\text { limestone) }\end{array}$} & calcite & $\begin{array}{c}3.8146(12), 3.2065(5), 3.0155(100), 2.4794(12), 2.2255(15), 2.0856(15) \\
1.9202(5), 1.9013(15), 1.8647(15), 1.6182(4), 1.5989(8), 1.5200(5) \\
1.5099(3), 1.4680(5)\end{array}$ \\
\hline & huntite & $2.8204(100)$ \\
\hline & ankerite & $2.9007(100)$ \\
\hline & quartz & $3.3239(100), 1.5595(2)$ \\
\hline \multirow{4}{*}{$\begin{array}{l}\text { Sample } 4 \\
\text { (Dziewkowice } \\
\text { limestone ) }\end{array}$} & calcite & $\begin{array}{c}3.8472(12), 3.0356(100), 2.4894(12), 2.2851(15), 2.0925(15), 1.9260(5) \\
1.9107(15), 1.8737(15), 1.6248(4), 1.6015(8), 1.5211(5), 1.5066(3) \\
1.4732(5)\end{array}$ \\
\hline & dolomite & $3.7049(4), 2.0108(10), 1.8244(3), 1.5876(2), 1.5571(4)$ \\
\hline & huntite & $2.8334(100)$ \\
\hline & quartz & $3.3361(100), 1.8075(12)$ \\
\hline \multirow{6}{*}{$\begin{array}{l}\text { Sample } 5 \\
\text { (Karchowice } \\
\text { limestone ) }\end{array}$} & calcite & $\begin{array}{l}3.8472(12), 3.0305(100), 2.4927(12), 2.2823(15), 2.0925(15), 1.9260(5) \\
\quad 1.9107(15), 1.8719(15), 1.6248(4), 1.5989(8), 1.5245(5), 1.5055(3)\end{array}$ \\
\hline & $\mathrm{Mg}$ - calcite & $2.9957(100), 2.5687(2), 1.8452(15)$ \\
\hline & dolomite & $\begin{array}{c}2.8915(100), 2.6728(4), 2.5336(3), 2.4057(7), 2.1944(15), 2.0675(3), \\
2.0150(10), 1.8041(10), 1.7844(12), 1.5667(2), 1.4649(2)\end{array}$ \\
\hline & huntite & $2.8291(100)$ \\
\hline & ankerite & $3.6973(1)$ \\
\hline & quartz & $3.3422(100), 1.5453(9)$ \\
\hline \multirow{6}{*}{$\begin{array}{l}\text { Sample } 6 \\
\text { (Karchowice } \\
\text { limestone) }\end{array}$} & calcite & $\begin{array}{c}3.8308(12), 3.0205(100), 2.4827(12), 2.0879(15), 1.9069(15), 1.8737(15), \\
1.6002(8)\end{array}$ \\
\hline & $\mathrm{Mg}$ - calcite & $2.9908(100), 2.2768(15), 1.8629(15)$ \\
\hline & dolomite & $\begin{array}{c}2.8779(100), 2.6690(4), 2.5406(3), 2.3964(7), 2.1893(15), 2.0129(10), \\
1.7975(10), 1.7827(12), 1.5655(2), 1.4639(2)\end{array}$ \\
\hline & huntite & $2.8247(100)$ \\
\hline & ankerite & $3.6748(1)$ \\
\hline & quartz & $3.3300(100), 1.5418(9)$ \\
\hline
\end{tabular}


in samples 5 and 6 (Karchowice limestones) (Table 2, Fig. 2e and 2f), magnesium calcite was identified, an unstable carbonate phase rarely found in Triassic limestones. In the diffractograms of all samples (Table 2, Fig. 2), the presence of quartz was determined; in five samples (samples 1, 2, 3, 5, 6), the presence of ankerite (Table 2, Fig. 2a, 2b, 2c, 2e and 2f); and in sample 2, illite and kaolinite (Table 2, Fig 2b).

\subsection{Results of microprobe measurements}

During the X-ray microanalysis, BSE images were taken of the microareas of the examined samples, and the quantitative chemical composition of the rocks was determined. In the case of EDS analysis, carried out in microarea 1 of sample 6 , element spectra were compiled at the analyzed points.

\section{Dziewkowice limestone from Szymiszów- sample 4}

Microarea 1 - WDS analysis

In microarea 1 of sample 4 , WDS analysis was carried out. The electronic image of this microarea (1) of sample 4 is presented in Figure 3. The chemical composition of the sample, determined by way of penetration, at selected points of microarea 1 of sample 4 is presented in Table 3. The carbonate phase present here is characterized by a diversified chemical composition due to the presence of $\mathrm{Ca}$ and $\mathrm{Mg}$. Enrichment in magnesium is identified around dark gray areas (Fig. 3). The phase enriched in magnesium takes up around 30\% of the microarea surface.

TABLE 3

Microprobe chemical analyses in first microarea of Dziewkowice limestone (sample 4)

TABELA 3

Ilościowy skład chemiczny mikroobszaru 1 wapienia dziewkowickiego (próbka 5)

\begin{tabular}{|c|c|c|c|c|c|c|c|c|c|c|c|c|}
\hline \multirow{2}{*}{$\begin{array}{l}\text { Point } \\
\text { number }\end{array}$} & \multicolumn{11}{|c|}{ Type of chemical element [\%mass] } & \multirow{2}{*}{ Total } \\
\hline & $\mathrm{O}$ & $\mathrm{C}$ & $\mathrm{Mg}$ & $\mathrm{Si}$ & $\mathrm{Al}$ & $\mathrm{Ca}$ & $\mathrm{K}$ & $\mathrm{Ba}$ & $\mathrm{Sr}$ & $\mathrm{Fe}$ & $\mathrm{Mn}$ & \\
\hline 1 & 48.35 & 10.85 & 16.18 & 0.00 & 0.04 & 23.07 & 0.03 & 0.84 & 0.00 & 0.64 & 0.00 & 100.00 \\
\hline 2 & 49.69 & 10.36 & 14.85 & 0.00 & 0.04 & 24.24 & 0.03 & 0.01 & 0.02 & 0.75 & 0.01 & 100.00 \\
\hline 3 & 50.31 & 8.22 & 15.36 & 0.00 & 0.03 & 25.79 & 0.04 & 0.00 & 0.01 & 0.24 & 0.00 & 100.00 \\
\hline 4 & 45.66 & 9.29 & 14.56 & 0.00 & 0.02 & 23.54 & 1.04 & 5.69 & 0.00 & 0.17 & 0.03 & 100.00 \\
\hline 5 & 45.65 & 8.66 & 0.42 & 0.00 & 0.00 & 45.15 & 0.04 & 0.02 & 0.00 & 0.02 & 0.04 & 100.00 \\
\hline 6 & 53.50 & 4.04 & 0.21 & 0.00 & 0.02 & 42.14 & 0.08 & 0.00 & 0.00 & 0.01 & 0.00 & 100.00 \\
\hline 7 & 44.74 & 11.07 & 0.27 & 0.00 & 0.00 & 43.84 & 0.04 & 0.01 & 0.00 & 0.03 & 0.00 & 100.00 \\
\hline 8 & 45.46 & 8.75 & 0.06 & 0.00 & 0.01 & 45.68 & 0.00 & 0.00 & 0.03 & 0.01 & 0.00 & 100.00 \\
\hline 9 & 43.45 & 9.80 & 3.49 & 0.00 & 0.01 & 43.14 & 0.03 & 0.01 & 0.00 & 0.06 & 0.01 & 100.00 \\
\hline
\end{tabular}




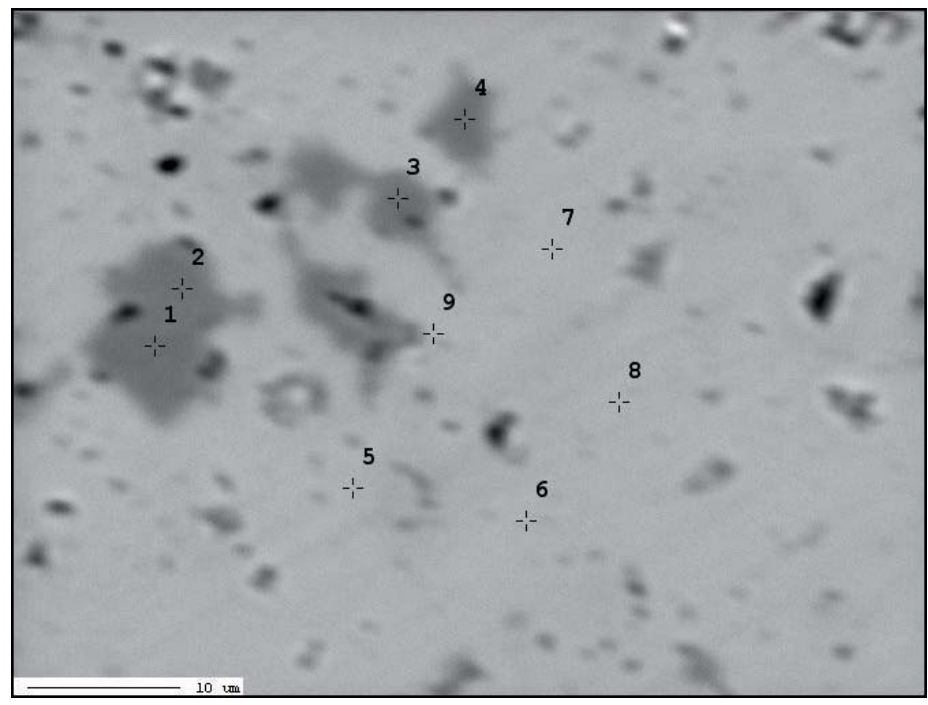

Fig. 3. BSE first image of sample 4 (Dziewkowice limestone from Szymiszów) Light grey - calcite, dark grey - carbonate phase rich in magnesium, 1-9 - points of chemical analysis, Magn. 500×

Rys. 3. Obraz BSE mikroobszaru 1 próbki 4 (wapień dziewkowicki z Szymiszowa) Jasnoszare - kalcyt, ciemnoszare - faza węglanowa bogata w magnez, 1-9 - miejsca wykonanych analiz chemicznych, Pow. 500×

The results of chemical analysis carried out in this microarea indicate the occurrence of two carbonate phases: low-magnesium calcite phase (Table 3 - points 5 to 9) and phase which could be treated as huntite phase (Table 3 - points 1 to 4). The content of Mg in the huntite phase varies in points from 14.56 to $16.18 \%$, and the content of $\mathrm{Ca}$ from 23.07 to $25.79 \%$. The content of $\mathrm{Mg}$ in this phase is lower than stoichiometric for huntite $20-21 \% \mathrm{Mg}$ (33-34\% $\mathrm{MgO}$ ). Thus this phase, according to the values of $\mathrm{Mg}$ and $\mathrm{Ca}$, is an intermediate form between dolomite and huntite. It could also be huntite weakened in $\mathrm{Mg}$ during diagenetic processes (dedolomitization). At all points of this microarea (Table 3), the presence of iron was determined. At many points the presence of aluminum and potassium was identified, and at some points small amounts of barium, strontium, and manganese. The presence of strontium and barium points to the occurrence of aragonite in the original carbonate sediment which, during the diagenetic processes, was transformed into low-magnesium calcite.

Microarea 2 - WDS analysis

A WDS analysis was also carried out in microarea 2 of sample 4 . The electron image of this microarea (2) of sample 4 is presented in figure 4 . The chemical composition of the sample, determined by way of penetration, at the selected points of microarea 2 of sample 4 is presented in Table 4 . The carbonate phase present here is characterized by a diversified chemical composition due to the presence of $\mathrm{Ca}$ and $\mathrm{Mg}$. Enrichment in magnesium is 
identified around dark gray areas (Fig.4). The phase enriched in magnesium takes up around $40 \%$ of the microarea surface.

The results of chemical analysis carried out in this microarea, at two points, indicate the occurrence of two carbonate phases - low-magnesium calcite phase (Table 4 - point 2) and phase treated as huntite (Table 4 - point 1). The content of $\mathrm{Mg}$ in the huntite is in point $15.95 \%$, and the content of $\mathrm{Ca} 23.95 \%$. As in the previous microarea of this sample, the content of $\mathrm{Mg}$ in this phase is lower than stoichiometric for huntite $-20-21 \% \mathrm{Mg}$ $(33-34 \% \mathrm{MgO})$. Thus the phase, identified in this microarea, is an intermediate form

Microprobe chemical analyses in second microarea of Dziewkowice limestone (sample 4)

Ilościowy skład chemiczny mikroobszaru 2 wapienia dziewkowickiego (próbka 5)

\begin{tabular}{|c|c|c|c|c|c|c|c|c|c|c|c|c|}
\hline \multirow{2}{*}{$\begin{array}{c}\text { Point } \\
\text { number }\end{array}$} & \multicolumn{11}{|c|}{ Type of chemical element [\%mass] } & \multirow{2}{*}{ Total } \\
\hline & $\mathrm{O}$ & $\mathrm{C}$ & $\mathrm{Mg}$ & $\mathrm{Si}$ & $\mathrm{Al}$ & $\mathrm{Ca}$ & $\mathrm{K}$ & $\mathrm{Ba}$ & $\mathrm{Sr}$ & $\mathrm{Fe}$ & $\mathrm{Mn}$ & \\
\hline 1 & 53.35 & 6.65 & 15.95 & 0.00 & 0.029 & 23.95 & 0.002 & 0.009 & 0.003 & 0.057 & 0.00 & 100.00 \\
\hline 2 & 53.259 & 5.944 & 0.332 & 0.00 & 0.006 & 40.41 & 0.002 & 0.000 & 0.017 & 0.010 & 0.02 & 100.00 \\
\hline
\end{tabular}

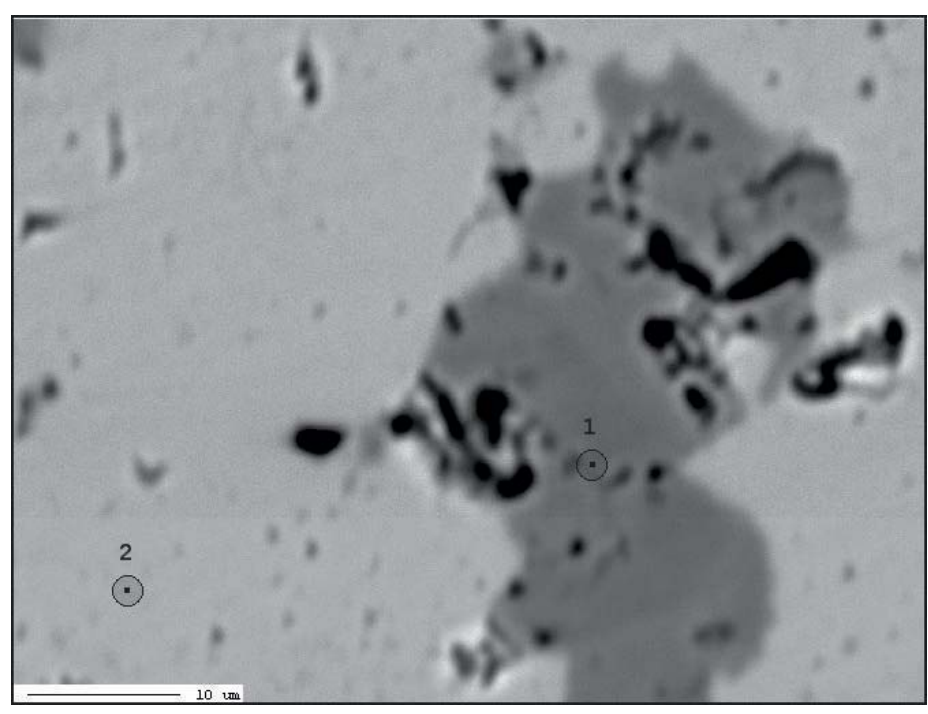

Fig. 4. BSE second image of sample 4 (Dziewkowice limestone from Szymiszów) Light grey - calcite, dark grey - carbonate phase rich in magnesium, 1-2 - points of chemical analysis, Magn. $500 \times$

Rys. 4. Obraz BSE mikroobszaru 2 próbki 4 (wapień dziewkowicki z Szymiszowa) Jasnoszare - kalcyt, ciemnoszare - faza węglanowa bogata w magnez, 1-9 - miejsca wykonanych analiz chemicznych, Pow. 500× 
between dolomite and huntite. It could also be huntite weakened in $\mathrm{Mg}$ during diagenetic processes (dedolomitization). At both points of this microarea (Table 4), a small amount of aluminum, potassium, iron, and strontium were determined; at point 1 - barium, and at point 2 - manganese. The presence of strontium and barium confirms the original occurrence of aragonite in the carbonate material.

\section{Karchowice limestone from Strzelce Opolskie- sample 5}

Microarea 1 - WDS analysis

In microarea 1 of sample 5, WDS analysis was carried out. The electron image of this microarea (1) of sample 5 is presented in Figure 5. The chemical composition of the specimen, determined by way of penetration, at the selected points of microarea 1 of sample 5 is presented in Table 5. The phase enriched in magnesium in this microarea comprises about $50 \%$ of the microarea surface. Similar to the case of the Dziewkowice limestone, this rock is also characterized by a diversified chemical composition of carbonate phase due to the content of $\mathrm{Ca}$ and $\mathrm{Mg}$. The enrichment in magnesium occurs in dark gray crystals of the carbonate mass (Fig. 5 - points 1 to 5 , Table 8 - points 1 to 5).

The results of the chemical analysis carried out at the points show that in microarea 1 of sample 6 there occur three carbonate phases - low-magnesium calcite (Table 5 - points 6 and 7), dolomite (Table 5 - point 5), and phase treated as huntite (Table 5- points 1 to 4). The content of $\mathrm{Mg}$ in huntite varies in the points from 14.36 to $14.93 \%$, and that of $\mathrm{Ca}$ from 22.49 to $23.01 \%$. The amount of $\mathrm{Mg}$ in the dolomite is $12.17 \%$ and $\mathrm{Ca} 22.20 \%$. The content of $\mathrm{Mg}$ in the huntite phase is, as in sample 4, lower than stoichiometric for huntite $-20-21 \% \mathrm{Mg}(33-34 \% \mathrm{MgO})$. Thus this phase identified in sample 5, according to the values of $\mathrm{Mg}$ and $\mathrm{Ca}$, is an intermediate form between dolomite and huntite. It could also be huntite weakened in $\mathrm{Mg}$ during diagenetic processes (dedolomitization). This theory also

TABLE 5

Microprobe chemical analyses in first microarea of Karchowice limestone (sample 5)

TABLE 5

Ilościowy skład chemiczny mikroobszaru 1 wapienia karchowickiego (próbka 5)

\begin{tabular}{|c|c|c|c|c|c|c|c|c|c|c|c|c|}
\hline \multirow{2}{*}{$\begin{array}{c}\text { Point } \\
\text { number }\end{array}$} & \multicolumn{11}{|c|}{ Type of chemical element [\%mass] } & \multirow{2}{*}{ Total } \\
\hline & $\mathrm{O}$ & $\mathrm{C}$ & $\mathrm{Mg}$ & $\mathrm{Si}$ & $\mathrm{Al}$ & $\mathrm{Ca}$ & K & $\mathrm{Sr}$ & $\mathrm{Ba}$ & $\mathrm{Fe}$ & $\mathrm{Mn}$ & \\
\hline 1 & 52.72 & 9.086 & 14.36 & 0.049 & 0.057 & 22.49 & 0.011 & 0.000 & 0.000 & 1.186 & 0.041 & 100.00 \\
\hline 2 & 50.11 & 11.015 & 14.58 & 0.044 & 0.065 & 22.84 & 0.014 & 0.000 & 0.016 & 1.307 & 0.009 & 100.00 \\
\hline 3 & 48.43 & 12.73 & 14.93 & 0.000 & 0.020 & 23.01 & 0.000 & 0.005 & 0.000 & 0.827 & 0.048 & 100.00 \\
\hline 4 & 48.74 & 12.636 & 14.41 & 0.000 & 0.019 & 22.99 & 0.000 & 0.000 & 0.027 & 1.138 & 0.040 & 100.00 \\
\hline 5 & 54.66 & 9.425 & 12.17 & 0.114 & 0.157 & 22.20 & 0.011 & 0.055 & 0.000 & 1.175 & 0.033 & 100.00 \\
\hline 6 & 47.82 & 10.978 & 0.225 & 0.128 & 0.070 & 40.57 & 0.045 & 0.000 & 0.000 & 0.144 & 0.020 & 100.00 \\
\hline 7 & 48.85 & 9.353 & 0.102 & 0.000 & 0.000 & 41.56 & 0.000 & 0.001 & 0.000 & 0.086 & 0.048 & 100.00 \\
\hline
\end{tabular}




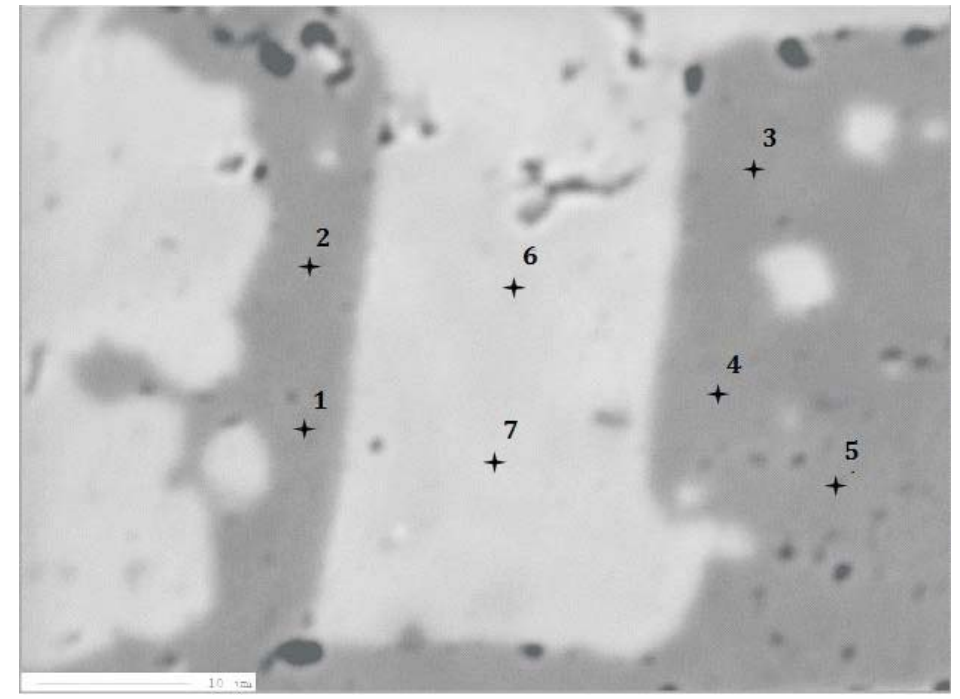

Fig. 5. BSE first image of sample 5 (Karchowice limestone from Strzelce Opolskie) Light grey - calcite, dark grey - carbonate phase rich in magnesium, $1-7-$ points of chemical analysis, Magn. $2000 \times$

Rys. 5. Obraz BSE mikroobszaru 1 próbki 5 (wapień karchowicki ze Strzelec Opolskich) Jasnoszare - kalcyt, ciemnoszare - faza węglanowa bogata w magnez, 1-7 - miejsca wykonanych analiz chemicznych, Pow. 2000×

confirmed the reduced value of $\mathrm{Mg}$ content in the dolomite. It is lower than the stoichiometric value of dolomite $-12.3 \% \mathrm{Mg}(21.8 \% \mathrm{MgO})$. At the points from 1 to 5 , higher content of iron was also determined as compared to points 6 and 7 , usually consisting of the substitution of magnesium in carbonate crystals containing $\mathrm{Mg}$. At all investigated points the presence of manganese was determined, and some points contained small amounts of silicon, aluminum, potassium, barium, and strontium (Table 5). The presence of strontium and barium confirms the original occurrence of aragonite in these rocks, an unstable carbonate phase which was transformed into low-magnesium calcite during diagenetic processes.

\section{Microarea 2 - WDS analysis}

WDS analysis was also carried out in microarea 2 of sample 5. The electron image of this microarea (2) of sample 5 is presented in Figure 6. The chemical composition of the sample, determined by way of penetration, at the selected points of microarea 2 of sample 5 is presented in Table 6 . The phase enriched in magnesium in this microarea comprises about $70 \%$ of the microarea surface. The carbonate phase of sample 6 in this microarea is characterized, similarly to microarea 1 , by diversified chemical composition due to the content of $\mathrm{Ca}$ and $\mathrm{Mg}$. Enrichment in magnesium occurs in dark gray crystals of carbonate mass (Fig. 6 - points from 1 to 5, Table 6 - points from 1 to 5 ).

The results of the chemical analysis carried out at these points show that in microarea 2 of sample 5 , similarly to microarea 1 , there occur three carbonate phases - low-magnesium 
Microprobe chemical analyses in second microarea of Karchowice limestone (sample 5)

TABELA 6

Ilościowy skład chemiczny mikroobszaru 2 wapienia karchowickiego (próbka5)

\begin{tabular}{|c|c|c|c|c|c|c|c|c|c|c|c|c|}
\hline \multirow{2}{*}{$\begin{array}{c}\text { Point } \\
\text { number }\end{array}$} & \multicolumn{11}{|c|}{ Type of chemical element [\%mass] } & \multirow{2}{*}{ Total } \\
\hline & $\mathrm{O}$ & $\mathrm{C}$ & $\mathrm{Mg}$ & $\mathrm{Si}$ & $\mathrm{Al}$ & $\mathrm{Ca}$ & $\mathrm{K}$ & $\mathrm{Ba}$ & $\mathrm{Sr}$ & $\mathrm{Fe}$ & $\mathrm{Mn}$ & \\
\hline 1 & 48.36 & 11.543 & 14.04 & 0.000 & 0.029 & 25.19 & 0.000 & 0.000 & 0.024 & 0.814 & 0.000 & 100.00 \\
\hline 2 & 47.32 & 12.902 & 14.01 & 0.000 & 0.017 & 24.78 & 0.000 & 0.000 & 0.000 & 0.971 & 0.000 & 100.00 \\
\hline 3 & 49.02 & 11.526 & 13.42 & 0.000 & 0.017 & 24.87 & 0.010 & 0.000 & 0.000 & 1.093 & 0.044 & 100.00 \\
\hline 4 & 46.59 & 12.187 & 14.72 & 0.000 & 0.033 & 24.99 & 0.001 & 0.080 & 0.000 & 1.399 & 0.000 & 100.00 \\
\hline 5 & 45.60 & 12.36 & 15.92 & 0.005 & 0.025 & 24.78 & 0.000 & 0.000 & 0.017 & 1.266 & 0.027 & 100.00 \\
\hline 6 & 42.82 & 14.967 & 0.186 & 0.000 & 0.017 & 41.88 & 0.000 & 0.000 & 0.000 & 0.109 & 0.021 & 100.00 \\
\hline 7 & 44.71 & 12.495 & 0.159 & 0.000 & 0.000 & 42.53 & 0.000 & 0.000 & 0.000 & 0.106 & 0.000 & 100.00 \\
\hline 8 & 43.18 & 12.445 & 0.104 & 0.000 & 0.000 & 44.02 & 0.000 & 0.008 & 0.000 & 0.238 & 0.005 & 100.00 \\
\hline
\end{tabular}

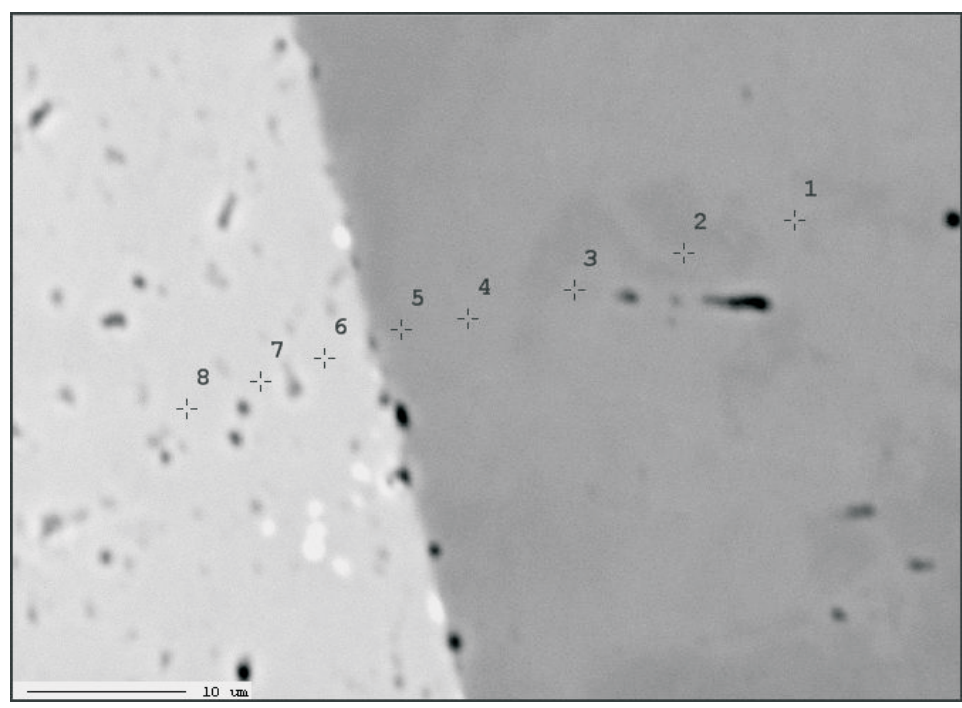

Fig. 6. BSE second image of sample 5 (Karchowice limestone from Strzelce Opolskie) Light grey - calcite, dark grey - carbonate phase rich in magnesium, 1-4 - points of chemical analysis, Magn. 2000×

Rys. 6. Obraz BSE mikroobszaru 2 próbki 5 (wapień karchowicki ze Strzelec Opolskich) Jasnoszare - kalcyt, ciemnoszare - faza węglanowa bogata w magnez, 1-4 - miejsca wykonanych analiz chemicznych, Pow. 2000× 
calcite (Table 6 - points 6, 7 and 8), dolomite (Table 6 - point 3), and carbonate phase treated as huntite (Tab.6 - points 1, 2, 4, and 5). The content of $\mathrm{Mg}$ in the huntite varies in the points from 14.01 to $15.92 \%$, and that of calcium from 24.78 to $25.19 \%$. The amount of $\mathrm{Mg}$ in the dolomite is in point $13.42 \%$ and $\mathrm{Ca} 24.87 \%$. At the points from 1 to 5 , at the places where huntite and dolomite occur, higher content of iron was also determined as compared to points 6,7 and 8, usually indicating the substitution of magnesium in carbonate crystals containing $\mathrm{Mg}$. At some points the presence of aluminum, potassium, manganese, barium, and strontium were determined (Table 6). The presence of strontium and barium confirms the original occurrence of aragonite in these rocks, an unstable carbonate phase which was transformed into low-magnesium calcite during diagenetic processes.

\section{Karchowice limestone from Strzelce Opolskie - sample 6}

Microarea 1 - WDS analysis in selected points

In microarea 1 of sample 6, WDS analysis was carried out. The electron image of this microarea (1) of sample 6 is presented in Figure 7. The chemical composition of the specimen, determined by way of penetration, at the selected points of microarea 1 of sample 6 is presented in Table 7. The phase enriched in magnesium takes up about $45 \%$ of the microarea surface. The carbonate phase present here is characterized by diversified chemical composition due to the presence of $\mathrm{Ca}$ and $\mathrm{Mg}$. Enrichment in magnesium occurs in dark gray crystals probably of huntite (Fig. 7 - points 1 and 2, Table 7 - points 1 and 2).

The results of chemical analysis carried out at the points demonstrate that in microarea 1 of sample 6 there occur two carbonate phases - low-magnesium calcite (Table 8 - points 3 and 4) and huntite (Table 8 - points 1 and 2). The content of Mg varies in points from 14.61 to $15.68 \%$, and that of calcium from 24.16 to $24.71 \%$. The content of $\mathrm{Mg}$ in the huntite phase is, as in previous samples, lower than stoichiometric for huntite $-20-21 \% \mathrm{Mg}$ (33-34\% MgO). Thus this phase identified in sample 6, according to the values of $\mathrm{Mg}$ and $\mathrm{Ca}$, is an intermediate form between dolomite and huntite. As in previous samples, the huntite of this sample could also be a weakened huntite phase in $\mathrm{Mg}$ resulting from diagenetic

TABLE 7

Microprobe chemical analyses in first microarea of Karchowice limestone (sample 6)

TABELA 7

Ilościowy skład chemiczny mikroobszaru 1 wapienia karchowickiego (próbka 6)

\begin{tabular}{|c|c|c|c|c|c|c|c|c|c|c|c|c|}
\hline \multirow{2}{*}{$\begin{array}{c}\text { Point } \\
\text { number }\end{array}$} & \multicolumn{11}{|c|}{ Type of chemical element [\% mass] } & \multirow{2}{*}{ Total } \\
\hline & $\mathrm{O}$ & $\mathrm{C}$ & $\mathrm{Mg}$ & $\mathrm{Si}$ & $\mathrm{Al}$ & $\mathrm{Ca}$ & $\mathrm{K}$ & $\mathrm{Ba}$ & $\mathrm{Sr}$ & $\mathrm{Fe}$ & $\mathrm{Mn}$ & \\
\hline 1 & 50.12 & 9.26 & 15.68 & 0.00 & 0.03 & 24.71 & 0.00 & 0.01 & 0.03 & 0.16 & 0.00 & 100.00 \\
\hline 2 & 56.13 & 4.68 & 14.61 & 0.00 & 0,06 & 24.16 & 0.00 & 0.01 & 0.04 & 0.28 & 0.03 & 100.00 \\
\hline 3 & 53.06 & 4.33 & 0.27 & 0.00 & 0.01 & 42.28 & 0.01 & 0.00 & 0.00 & 0.03 & 0.01 & 100.00 \\
\hline 4 & 51.37 & 6.69 & 0.21 & 0.00 & 0.02 & 41.67 & 0.00 & 0.00 & 0.00 & 0.03 & 0.01 & 100.00 \\
\hline
\end{tabular}




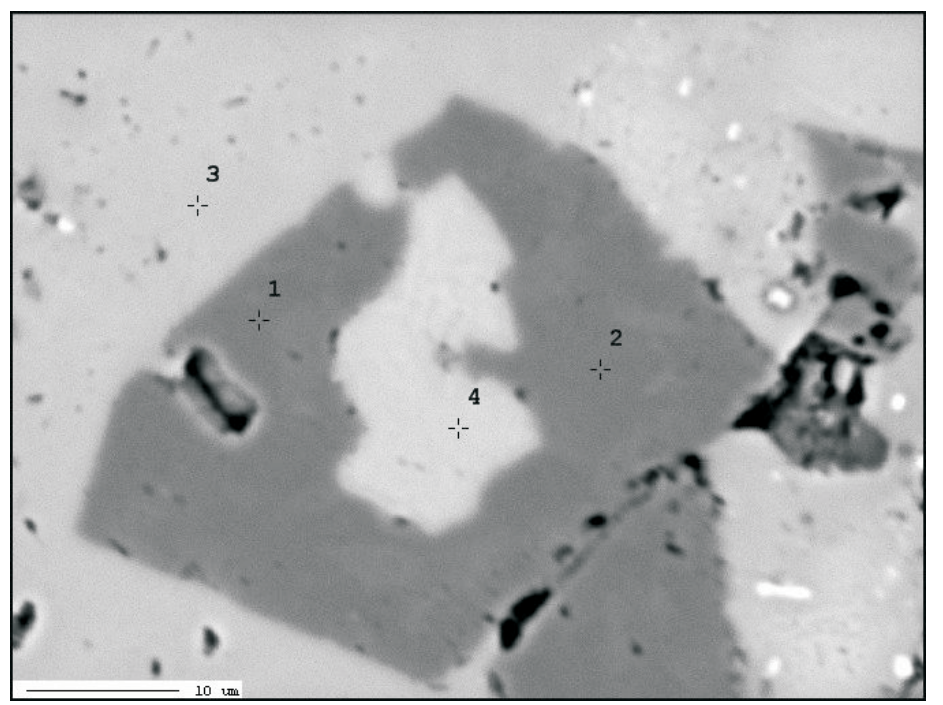

Fig. 7. BSE first image of sample 6 (Karchowice limestone from Strzelce Opolskie) Light grey - calcite, dark grey - carbonate phase rich in magnesium, $1-4-$ points of chemical analysis, Magn. $2000 \times$

Rys. 7. Obraz BSE mikroobszaru 1 próbki 6 (wapień karchowicki ze Strzelec Opolskich) Jasnoszare - kalcyt, ciemnoszare - faza weglanowa bogata w magnez, 1-2 - miejsca wykonanych analiz chemicznych, Pow. 500×

processes (dedolomitization). At points 1 and 2, a higher content of iron was also determined when compared to points 3 and 4, usually stemming from the substitution of magnesium in carbonate crystals containing Mg. At all the investigated points, the presence of aluminum was determined, and some points contained small amounts of potassium, manganese, barium, and strontium (Table 7). The presence of strontium and barium confirms the original occurrence of aragonite in these rocks, an unstable carbonate phase which was transformed into low-magnesium calcite during diagenetic processes.

On the basis of the microprobe measurement results, it was possible to compare the $\mathrm{Mg}$ and $\mathrm{Ca}$ values of dolomite and huntite with stoichiometric values. The stoichiometric content of $\mathrm{Mg}$ in dolomite is $13.18 \%(21.86 \% \mathrm{MgO})$, while in huntite it is $20.65 \%(34.25 \% \mathrm{MgO})$ higher than in dolomite. The content of $\mathrm{Ca}$ in dolomite is $21.73 \%(30.41 \% \mathrm{CaO})$, while in huntite the value present was $11.35 \%(15.88 \% \mathrm{CaO})$ (http://www.webmineral.com/data/Dolomite.shtml;

http://webmineral.com/data/Huntite.shtml).

The $\%$ results of microprobe measurements show that in some points of the analyzed microareas, the value of $\mathrm{Mg}$ is higher than stoichiometric for dolomite, so this carbonate phase could not be treated as dolomite. The $\mathrm{Mg}$ value is also lower than stoichiometric for huntite. Thus this carbonate phase could be treated as huntite which underwent diagenetic procceses (probably dedolomitization?). The effect of diagenetic changes was the reduction in magnesium content in the huntite crystal. Because of this, the $\mathrm{Mg} / \mathrm{Ca}$ ratio for huntite was 
not calculated. The $\mathrm{Mg} / \mathrm{Ca}$ mole ratios of huntite range between 2.04 and 3.85, with an average of 2.77 (Yavuz et al. 2006).

\section{Conclusions}

The results of the studies showed that the Triassic carbonate rocks of the shelly limestone of the Opole Silesia Region contain a mineral which could be treated as huntite - magnesium and calcium carbonate with the chemical formula $\mathrm{CaMg}_{3}\left[\mathbf{C O}_{3}\right]_{4}$. This is a specific carbonate phase with increased content of magnesium which can occur in rocks of various types such as magmatic, sedimentary, and metamorphous rocks, in sediments of various geological periods. Huntite is usually formed as an effect of hydrothermal processes, weathering of dolomite, or as a result of the transformation of magnesium calcite under high temperature conditions. In sedimentary rocks, it occurs in the sediments of the vadose zone (Deelman 2011).

In the case of FTIR analysis, the presence of huntite was confirmed by the occurrence in absorption spectra of bands $1555 \mathrm{~cm}^{-1}$ (in samples 1 and 4), $1562 \mathrm{~cm}^{-1}$ (in sample 3), $1572 \mathrm{~cm}^{-1}$ (in sample 2) (Ramseyer et al. 1997; http://rruff.info/Huntite). Due to the fact that this carbonate phase was identified by applying the FTIR method only on the basis of single bands, it was necessary to apply other research methods in order to confirm the presence of huntite in the Triassic carbonate rocks of the Opole Silesia Region. Furthermore, this mineral was identified using FTIR analysis only in the limestones of the Gogolin, Górażdże, and Dziewkowice (Terebratule) layers. There were small amounts of this carbonate phase mixed with other minerals among which low magnesium calcite and dolomite predominate.

X-ray analysis also made it possible to identify carbonate phase enriched in magnesium, treated as huntite, in the limestones of the Karchowice layers. The presence of this mineral was identified based on the presence of a diffraction line of the highest intensity ( $d_{\text {hkl }}$ value - $2.83 \AA$ ) (Dollase, Reeder 1986; http://webmineral.com/data/Huntite.shtml) in the diffractograms of all six investigated samples. The occurrence of a single diffraction line - although of the highest intensity - could indicate the probable presence of huntite in the examined limestones, and a very low amount of this carbonate phase.

Based on the research carried out in the microareas, the presence of huntite in Dziewkowice and Karchowice limestones was determined. The increased content of magnesium identified at the points where this carbonate phase occurs varies from $14.01 \% \mathrm{Mg}(23.23 \%$ $\mathrm{MgO})$ to $16.18 \% \mathrm{Mg}(26.83 \% \mathrm{MgO})$. It considerably exceeds the stoichiometric value for dolomite $(21.86 \% \mathrm{MgO}, 13.12 \% \mathrm{Mg})$. The diversification of the amount of magnesium in dolomite can be demonstrated as follows: $\mathbf{C a}_{\mathbf{0 , 5}} \mathbf{M g}_{\mathbf{0}, 5} \mathbf{C O}_{3}$ (spatial group R3c), whereas in huntite the relation assumes the form of $\mathbf{C a}_{\mathbf{0}, 25} \mathbf{M g}_{\mathbf{0}, 75} \mathbf{C O}_{\mathbf{3}}$ (spatial group R32) (Böttcher et al. 1997).

When analyzing the possibilities involving the formation of huntite, carbonate phase enriched in magnesium to a higher extent than Mg-calcite or dolomite, we can assume that 
this mineral was formed in the areas of the Germanic basin in which diagenesis processes were taking place with the contribution of waters from the vadose zone.

The content of $\mathrm{Mg}$ in the huntite phase in all studied samples is lower than stoichiometric for huntite - 20-21\% Mg (33-34\% MgO). Because of this, the phase could be treated as an intermediate form between dolomite and huntite. This theory also confirmed the reduced value of $\mathrm{Mg}$ content in the dolomite of sample 5. It is lower than the stoichiometric value of dolomite $-12.3 \% \mathrm{Mg}(21.8 \% \mathrm{MgO})$. This could also be huntite weakened in $\mathrm{Mg}$ during diagenetic processes (dedolomitization). Dolomite, however, was probably formed in the mixing zone of the waters from the phreatic zone and salty sea waters in the early period of constructive diagenesis, an effect of the dolomitization processes. Such conditions thus brought about the formation of carbonate cement enriched in magnesium. Most probably, owing to the presence of waters of this zone which had an elevated content of dissolved mineral components, the fixation process of magnesium calcite unstable carbonate phase originally formed in the environment of the seabed took place.

To confirm the occurrence of huntite in Triassic, Muschelkalk Limestones of the Opole Silesia Region, more limestone samples should be studied using different methods. Advanced research could also provide the opportunity to explain the conditions of the environment in which the carbonate phase enriched in magnesium-huntite was formed.

\section{REFERENCES}

Ahn et al. 1996 - Ahn D.J., Berman A., Charych D., 1996 - Probing the dynamics of template-directed calcite crystallization with in situ FTIR. J. Phys. Chem., 100, s. 12455-12461.

B olewski A., Żabiński W., 1988 - Metody badań minerałów i skał. Wyd. Geologiczne, Warszawa.

Böttcher et al. 1997 - Böttch er M.E., Gehlken P.L., S te el e F.D., 1997 - Characterization of inorganic and biogenic magnesian calcites by Fourier Transform infrared spectroscopy. Solid State Ionics, 101-103, s. 1379-1385.

Cole W.F., La n c u c k i C.J., 1975 - Huntite from Deer Park, Victoria, Australia. American Mineralogist Volume $60,1130-1131$.

D e e $1 \mathrm{~m}$ a n J.C., 2011 - Low-temperature formation of dolomite and magnesite. http://www.jcdeelman.demon.nl/dolomite/files/13_Chapter6.pdf

Dollas e W.A., Reeder R.J., 1986 - Crystal structure refinement of huntite, $\mathrm{CaMg}_{3}\left[\mathrm{CO}_{3}\right]_{4}$, with X-ray powder data. American Mineralogist Volume 71, 163-166.

F a u s t G.T., 1953 - Huntite, $\mathrm{Mg}_{3} \mathrm{Ca}\left(\mathrm{CO}_{3}\right)_{4}$, a new mineral. American Mineralogist Volume 38, 4-23.

Paw loski G.A., 1985 - Quantitative determination of mineral content of geological samples by X-ray diffraction. American Mineralogist, Volume 70, p. 663-667.

Pokrovsky et al. 2000 - Pokrovsky O.S., Mielczarski J.A., Barrea O., Schott J., 2000 - Surface spaciation models of calcite and dolomite aqueous solution interfaces and their spectroscopic evaluation. Langmuir 16, s. 2677-2688.

Ramseyer et al. 1997 - Ramseyer K., Miano T.M., D 'Orazio V., Wildberger A., Wagner T., Geister J., 1997 - Nature and origin of organic matter in carbonates from speleothems, marine cements and coral skeletons. Org. Geochem., Vol. 26, No 5/6, s. 361-378.

Stanienda K., 2006 - Minerały węglanowe w skałach triasu rejonu Tarnowa Opolskiego. Gospodarka Surowcami Mineralnymi t. 22, z. spec. 3, IGSMiE PAN, Kraków 2006, s. 243-251. 
St a n i en da K., 2011 - Przejawy dolomityzacji w wapieniach triasowych złoża 'Tarnów Opolski'. Monografia, Wydawnictwo Politechniki Śląskiej, Gliwice.

Stanienda et al. 2012 - Stanienda K., Nowak J., Kukiełka T., 2012 - Fazy mineralne w triasowych skałach węglanowych rejonu Chorzowa. Gospodarka Surowcami Mineralnymi t. 28, z. 3, IGSMiE PAN, Kraków, s. 71-91.

S zu lc J ., 1990 - International Workshop - Field Seminar The Muschelkalk- Sedimentary Environments, Facies and Diagenesis - Excursion Guidebook and Abstracts. Kraków-Opole, s. 1-32.

Szulc J., 2000 - Middle Triassic evolution of the Northern Peri-Tethys area is influenced by early opening of the Tethys Ocean. Annales Societatis Geologorum Poloniae, vol. 70, s. 1-48.

Yavuz et al. 2006 - Yavuz F., Kırıkoğlu M.S., Özden G., 2006 - The occurrence and geochemistry of huntite from Neogene lacustrine sediments of the Yalvaç-Yarıkkaya Basin, Isparta, Turkey. N. Jb. Miner. Abh., Vol. 182/2, p. 201-212, Stuttgart, April 2006, published online 2006.

http://rruff.info/Huntite

http://www.webmineral.com/data/Dolomite.shtml

http://webmineral.com/data/Huntite.shtml

\section{HUNTYT W WAPIENIACH TRIASOWYCH ŚLĄSKA OPOLSKIEGO}

\section{Słowa kluczowe}

Śląsk Opolski, wapień muszlowy, wapienie, huntyt, spektroskopia Fourierowska, analiza rentgenostrukturalna, badania w mikroobszarach

\section{Streszczenie}

W niniejszym artykule przedstawiono wyniki badań próbek skał węglanowych pobranych z utworów triasowych, w obszarze Śląska Opolskiego. Przedmiotem badań była identyfikacja huntytu - fazy węglanowej, o podwyższonej, w porównaniu z kalcytem magnezowym i dolomitem, zawartości magnezu. Huntyt powstaje zwykle wskutek procesów hydrotermalnych, wietrzenia dolomitu lub w wyniku przeobrażenia, w warunkach wysokich temperatur, kalcytu magnezowego. W skałach osadowych występuje w utworach strefy wadycznej (aeracji).

W celu stwierdzenia obecności huntytu, wybrane próbki skał poddano analizom FTIR, rentgenowskiej oraz badaniom w mikroobszarach. Minerał ten zidentyfikowano w skałach wapienia muszlowego, w wapieniach warstw gogolińskich, górażdżańskich, dziewkowickich i karchowickich. W przypadku analizy FTIR, o obecności huntytu świadczy występowanie w widmach absorpcyjnych, w próbkach 1 i 4 pasma $1555 \mathrm{~cm}^{-1}$, w próbce $3-$ pasma $1562 \mathrm{~cm}^{-1}$, a w próbce 2 - pasma $1572 \mathrm{~cm}^{-1}$. W dyfraktogramach rentgenowskich wszystkich badanych próbek, fazę węglanową uznaną za huntyt zidentyfikowano na podstawie linii dyfrakcyjnej, o najwyższej intensywności i wartości $d_{h k l}-2,83 \AA$. Badania w mikroobszarach pozwoliły na zidentyfikowanie huntytu w wapieniach dziewkowickich oraz karchowickich. Oznaczone w punktach mikroobszarów badanych próbek, zawartości magnezu, wahają się od 14,01\% Mg (23,23\% MgO) do 16,18\% Mg (26,83\% MgO). Wartości te przekraczają znacznie wartość stechiometryczną, typową dla dolomitu (21,86\% MgO, 13,12\% Mg). Oznaczona w mikroobszarach ilość magnezu w huntycie jest jednak niższa od wartości stechiometrycznej dla tej fazy węglanowej, która wynosi 20,65\% Mg (34,25\% MgO). Prawdopodobnie, wskutek procesów diagenezy (dedolomityzacja ?) mogło dojść do usunięcia części jonów magnezu z kryształów huntytu.

Analizując możliwości tworzenia się huntytu, fazy węglanowej o podwyższonej zawartości magnezu, w większym stopniu niż Mg-kalcyt czy dolomit, można podejrzewać, że minerał ten powstał w obszarach zbiornika germańskiego, w których procesy diagenezy zachodziły przy udziale wód strefy wadycznej. 


\section{POSSIBILITY OF HUNTITE PRESENCE IN THE TRIASSIC LIMESTONES OF OPOLE SILESIA}

\section{Key words}

Opole Silesia, Muschelkalk, limestone, huntite, Fourier Spectroscopy, X ray diffraction, microprobe measurements

\section{Abstract}

This article presents the results of studies of Triassic carbonate rock samples taken from the area of Opole Silesia. The aim of the study was the identification of a huntite-carbonate phase characterized by a higher content of magnesium in comparison with magnesium calcite and dolomite. Huntite is usually formed during hydrothermal processes or weathering of dolomite. It could be also a product of magnesium calcite transformation under high temperatures. In sedimentary rocks, this mineral occurs in deposits of the vadose-water zone.

Selected rock samples were examined using FTIR spectrometry, X-ray diffraction, and microprobe measurements. Huntite was identified in Muschelkalk rocks, in the limestones of the Gogolin Beds, Górażdże Beds, Dziewkowice Beds, and Karchowice Beds. Results of FTIR spectrometry showed that in the infrared absorption curves of the analyzed samples, there occurred an absorption band of $1555 \mathrm{~cm}^{-1}$ in samples 1 and 4 , in sample 3 an absorption band of $1562 \mathrm{~cm}^{-1}$, and in sample 2 an absorption band of $1572 \mathrm{~cm}^{-1}$. These absorption bands are typical for huntite. In X-ray diffraction patterns, carbonate phase treated as huntite was identified on the basis of a diffraction line which presented the highest intensity and $\mathrm{d}_{\mathrm{hkl}}$ value $-2.83 \AA$. Results of microprobe measurements delivered extensive information. This method allowed for the identification of huntite in limestones of the Dziewkowice and Karchowice Beds. The amounts of magnesium determined in selected points of the examined samples varied from $14.01 \% \mathrm{Mg}(23.23 \% \mathrm{MgO})$ to $16.18 \% \mathrm{Mg}(26.83 \% \mathrm{MgO})$. These values are higher than magnesium values typical for $\mathrm{Mg}$-calcite. They also exceed the stoichiometric value typical for dolomite $(21.86 \% \mathrm{MgO}, 13.12 \% \mathrm{Mg})$. The content of $\mathrm{Mg}$ measured for huntite in the points of the microareas is lower than the stoichiometric value for this carbonate phase $(20.65 \% \mathrm{Mg}, 34.25 \% \mathrm{MgO})$. The reduction in magnesium ions could be the effect of diagenetic processes (dedolomitization?).

Analyzing the possibilities of huntite formation, the carbonate phase characterized by an amount of magnesium higher than in Mg-calcite and dolomite, it can be hypothesized that this mineral was formed in areas of the Germanic Basin where diagenetic processes were occurring with the contribution of waters of the vadose zone. 